\title{
DOKTER, PASIEN DAN MALPRAKTIK
}

\author{
Wahyu Wiriadinata* \\ Balai Pendidikan dan Latihan Kejaksaan Agung RI \\ Jalan Harsono, Ragunan, Jakarta Selatan, D.K.I. Jakarta, 12550
}

\begin{abstract}
The purpose of this paper is to answer the questions and problems that give a rise to disputes between physicians and their patient and the liabilities of physicians to their patients in case a malpractice. The research method used was a juridical-normative approach, by studying applicable legislations, both contained in laws themselves and in legal references/books. The result in a juridical aspect was written in a descriptive-analytical form. The conclusion of this paper is: that disputes have occurred due to malpractices that the physicians committed to their patients, and that physicians' liability involved criminal, private, and administrative aspects.
\end{abstract}

Keywords: physician, patient, malpractice, liability.

\section{Intisari}

Tulisan ini, bertujuan untuk menjawab pertanyaan dan masalah penyebab perselisihan antara dokter dengan pasien dan pertanggungjawaban dokter terhadap pasien dalam hal terjadi malpraktik. Metode penulisan yang digunakan yaitu pendekatan yuridis normatif, dengan mempelajari peraturan perundang-undangan, baik yang ada dalam undang-undang itu sendiri maupun yang ada dalam literatur/buku ilmu pengetahuan hukum. Hasilnya berupa aspek yuridis dituangkan dalam bentuk deskriptif analitis. Adapun kesimpulan dari tulisan ini adalah: Perselisihan terjadi akibat dari malpraktik dokter terhadap pasien dan pertanggungjawaban dokter meliputi pidana, perdata dan etik.

Kata Kunci: dokter, pasien, malpraktik, pertanggungjawaban.

\section{Pokok Muatan}

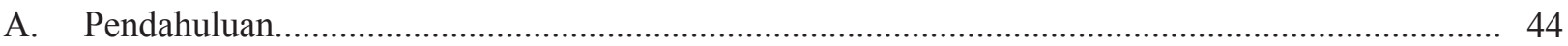

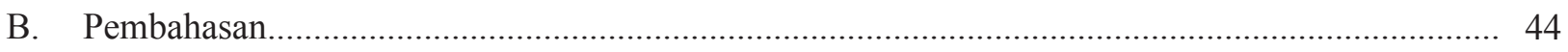

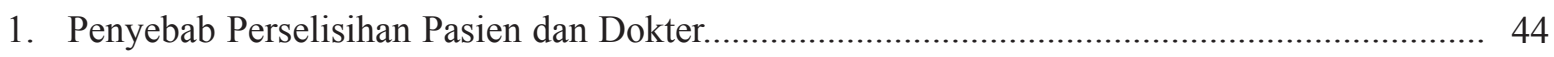

2. Pertanggungjawaban Dokter terhadap Pasien Dalam Hal Malpraktik...................................... 49

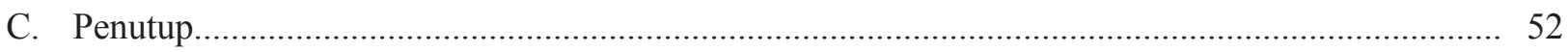




\section{A. Pendahuluan}

Dalam menegakkan hukum ada tiga unsur yang harus diperhatikan, yaitu unsur kepastian hukum, kemanfaatan, dan keadilan. Dengan adanya kepastian hukum masyarakat akan lebih tertib. Masyarakat juga mengharapkan manfaat yang dapat diperoleh dari ditegakkannya hukum itu. Dalam pelaksanaan penegakan hukum masyarakat mengharapkan juga agar hukum bisa memberikan keadilan bagi kepentingan mereka. ${ }^{1}$ Kemanfaatan dalam penegakan hukum salah satunya dimaksud untuk pembangunan masyarakat, termasuk di dalamnya pembangunan kesehatan masyarakat.

Pembangunan kesehatan masyarakat diarahkan untuk meningkatkan derajat kesehatan, sangat besar artinya bagi pembangunan dan pembinaan sumber daya manusia Indonesia dan juga sebagai modal bagi pelaksanaan pembangunan nasional yang pada hakikatnya adalah pembangunan manusia Indonesia seutuhnya dan pembangunan seluruh masyarakat Indonesia. Ini merupakan usaha dalam rangka mengemban amanah sebagaimana termuat dalam UUD 1945 Pasal 34 ayat (3) "Negara bertanggung jawab atas penyediaan fasilitas pelayanan kesehatan dan fasilitas pelayanan umum yang layak". Dokter merupakan soko guru dalam menjelmakan cita-cita dalam Pasal 34 ayat (3) UUD 1945 tersebut dimaksud.

Penyelenggaraan pembangunan kesehatan meliputi upaya kesehatan dan sumber dayanya, harus dilakukan secara terpadu dan berkesinambungan guna mencapai hasil yang optimal. Upaya kesehatan yang semula dititikberatkan pada upaya penyembuhan penderita secara berangsur-angsur berkembang ke arah keterpaduan upaya kesehatan yang menyeluruh. Oleh karena itu, pembangunan kesehatan yang menyangkut upaya peningkatan kesehatan, pencegahan penyakit, penyembuhan penyakit, dan pemulihan kesehatan harus dilaksanakan secara menyeluruh, terpadu dan berkesinambungan, dan dilaksanakan bersama antara pemerintah dan masyarakat, termasuk dokter di dalamnya.
Memperoleh pelayanan kesehatan adalah hak asasi setiap manusia yang tanggungjawab pelaksanaannya ada pada pemerintah. Pemerintah menyadari rakyat yang sehat merupakan aset dan tujuan utama dalam mencapai masyarakat adil makmur. Oleh karenanya pemerintah berkewajiban menyelenggarakan upaya kesehatan yang merata dan terjangkau oleh masyarakat, membiayai pelayanan kesehatan yang bersifat public goods seperti imunisasi, pemberantasan penyakit menular, dan kewajiban membiayai pelayanan kesehatan orang miskin dan usia lanjut. Pada dasarnya perubahan hubungan antara dokter dan pasien sejalan pula dengan perkembangan ilmu dan teknologi, baik di bidang hukum maupun ilmu kedokteran sendiri, dan juga disebabkan oleh bertumbuhnya kesadaran hukum masyarakat khususnya Indonesia, sebagai salah satu hasil pembangunan.

Perubahan karakteristik masyarakat dan dokter sebagai pemberi jasa, dan perubahan masyarakat sebagai pengguna jasa kedokteran tersebut, bila tidak didukung oleh peningkatan komunikasi antara dokter dan pasien dapat menimbulkan ketidakpuasan dan konflik antara keduanya. Konflik itu sering terjadi akibat dari malpraktik yang dilakukan oleh dokter terhadap pasiennya. Konflik itu terbukti dengan antara lain masih rendahnya tingkat kesehatan masyarakat dan masih banyaknya kesalahan dalam pengobatan pasien yang menimbulkan cacat atau kematian. Berdasarkan uraian di atas, ada beberapa pokok permasalahan dalam tulisan ini, yaitu apa penyebab perselisihan/konflik antara dokter dengan pasien? Bagaimana pertanggungjawaban dokter terhadap pasien dalam hal terjadi malpraktek oleh dokter?

\section{B. Pembahasan}

\section{Penyebab Perselisihan Pasien dan Dokter}

a. Hukum Kedokteran dan Hukum Kesehatan

Hukum kedokteran diberi pengertian sebagai hukum yang mengatur produk profesi dokter, disebabkan karena adanya

Rena Yulia, "Perlindungan Hukum terhadap Korban Kejahatan”, Jurnal Wawasan Hukum, Vol. 18, No. 1, Febru ari 2008, hlm. 57. 
hubungan dengan pihak lain, baik itu pasien maupun tenaga kesehatan yang lain. Dengan demikian hanya menyangkut profesi dokter, ${ }^{2}$ atau dengan lain kata "sekelompok manusia dalam masyarakat sebagai satu sistem, yang memiliki keahlian dan keterampilan khusus". ${ }^{3}$

Indonesia belum memiliki hukum kedokteran dalam arti yang tersusun dalam suatu Undang-Undang tersendiri (terkodifikasi). Hukum yang ada barulah hukum kesehatan yang dimuat dalam UU No. 23 Tahun 1992 tentang Kesehatan. Namun bertolak dari ketentuan-ketentuan yang terdapat dalam UU No. 23 Tahun 1992 tersebut dapat diadakan studi, ketentuan pasal-pasal mana yang mengatur hubungan dokter sebagai satu pihak dengan pasien atau dengan tenaga kesehatan lainnya di lain-pihak, khususnya dalam upaya pelayanan kesehatan. Hubungan-hubungan hukum yang diatur di dalam UU No. 23 Tahun 1992 tentang Kesehatan dapat dikaitkan dengan hukum perdata dan hukum pidana umum yang diatur dalam Burgerlijk Wetboek/KUHPerdata dan Kitab Undang-Undang Hukum Pidana (KUHP).

Norma yang ada dalam hukum kesehatan merupakan kaidah yang mengatur seluruh aspek yang berkaitan dengan upaya dan pemeliharaan di bidang kesehatan. Perbedaan antara hukum kesehatan dan hukum kedokteran, terletak pada ruang lingkupnya saja. Ruang lingkup hukum kesehatan meliputi semua aspek yang berkaitan dengan kesehatan, yaitu kesehatan badaniah, rohaniah dan sosial secara keseluruhan. Sedangkan ruang lingkup hukum kedokteran hanya pada masalah-masalah yang berkaitan dengan profesi kedokteran. Karena masalah kedokteran juga termasuk di dalam ruang lingkup ke- sehatan, maka sebenarnya hukum kedokteran adalah bagian dari hukum kesehatan. Dilihat dari hakikatnya, baik hukum kesehatan maupun hukum kedokteran merupakan penerapan dari perangkat hukum perdata, pidana dan tata usaha negara dalam bidang kesehatan.

\section{b. Rumah Sakit}

Rumah sakit adalah salah satu tempat untuk pasien berobat dan dokter melayani pasien dalam hal pengobatan dan pemulihan kesehatan. Pengertian Rumah Sakit diatur oleh Anggaran Dasar Perhimpunan Rumah Sakit Seluruh Indonesia (PERSI) Bab I Pasal 1: "Bahwa rumah sakit adalah suatu sarana dalam mata rantai sistem kesehatan nasional yang mengemban tugas pelayanan kesehatan untuk seluruh masyarakat".

Rumah sakit adalah" "Suatu sarana yang merupakan bagian dari sistem pelayanan kesehatan yang menjalankan rawat inap, rawat jalan dan rehabilitasi berikut segala penunjangnya". Dengan demikian rumah sakit adalah tempat untuk menyelenggarakan salah satu upaya kesehatan yaitu upaya pelayanan kesehatan. Dalam hubungan hukum sebagai suatu sistem sosial, rumah sakit merupakan organ yang mempunyai kemandirian untuk melakukan perbuatan hukum. Rumah sakit bukan persoonlijke yang dapat berbuat dalam lalu lintas hukum dalam masyarakat sebagai manusia (natuurlijk persoon), namun rumah sakit diberi kedudukan menurut hukum sebagai "persoon" dan karenanya rumah sakit merupakan "rechtpersoon". Hukum yang telah menjadikan rumah sakit sebagai "rechtspersoon" dan oleh karena itu rumah sakit juga mempunyai hak dan kewajiban hukum atas tindakan yang dilakukannya. Untuk berbuat hukum sebagai subyek hukum inilah

Dokter dan dokter gigi sebagai salah satu jenis tenaga kesehatan yang menurut ketentuan Pasal 2 ayat (1) jo. PP No. 32 Tahun 1996 tentang Tenaga Kesehatan merupakan jenis tenaga medis, khususnya dalam huruf a.

Pasal 4 ayat (1) dan (3) jo. Pasal 5 ayat (1) dan (2) jo. Peraturan Pemerintah No. 32 Tahun 1996 tentang Tenaga Kesehatan.

Panitia Etika Rumah Sakit, 1991, Etika Rumah Sakit di Rumah Sakit Dr. Cipto Mangunkusumo, RS Rumah Sakit Dr. Cipto Mangunkusumo, Jakarta, hlm. 1. 
rumah sakit melibatkan seorang berprofesi kedokteran atau tenaga kesehatan yang tidak hanya terdiri dari para dokter dan dokter gigi tetapi semua jenis kesehatan.

Persetujuan untuk melakukan pekerjaan, seorang dokter diatur dalam Pasal 1601 BW berdasarkan syarat-syarat tertentu dengan menerima upah. Syarat-syarat yang dimaksudkan dapat dituangkan dalam deskripsi tugas yang dibuat rumah sakit sebagai badan hukum selaku pihak yang memberi pekerjaan dan tenaga kesehatan yang terlibat sebagai penerima pekerjaan. Dalam kenyataannya dokter yang bekerja di rumah sakit dapat digolongkan sebagai "dokter karyawan dan dokter tamu”. Dokter karyawan rumah sakit, datang pada saat jam kerja dan melakukan pelayanan medis pada jam dinasnya untuk dan atas nama rumah sakit dan terikat kepada. peraturan-peraturan yang terdapat dalam rumah sakit. Sedangkan dokter tamu bekerjanya insidental (tidak tetap).

\section{c. Kelalaian}

Kelalaian medis adalah suatu keadaan dimana seseorang bertindak kurang hati-hati menurut ukuran wajar. Karena tidak melakukan apa yang seharusnya seseorang itu. Kelalaian mencakup 2 (dua) hal, yakni: Pertama, karena melakukan sesuatu yang seharusnya tidak dilakukan; atau Kedua, karena tidak melakukan sesuatu yang seharusnya dilakukannya. Kelalaian atau negligence menurut Keeton Medical Negligence - The Standard of Care, $1980^{5}$ adalah suatu sikap - tindak yang oleh masyarakat dianggap menimbulkan bahaya secara tidak wajar dan diklasifikasikan demikian karena orang itu bisa membayangkan atau seharusnya membayangkan bahwa tindakan itu bisa mengakibatkan orang lain harus menanggung risiko, dan bahwa sifat dari risiko itu sedemikian beratnya, sehingga seharusnya ia bertindak dengan cara yang lebih hati-hati.

Profesi dokter harus tunduk dan men- taati norma-norma umum termasuk norma sebagaimana disuratkan pada pendapat tersebut di atas (KUHPerdata dan KUHP), juga teliti dan hati-hati. Norma berfungsi untuk mewujudkan tata tertib di dalam masyarakat, sehingga hubungan manusia berjalan lancar dan tertib. Seorang dokter bisa dinilai bertanggung jawab terhadap profesional negligence apabila sikap atau perbuatannya tidak berdasarkan standar yang umum berlaku pada profesinya, sehingga pasien sampai cedera karena kelalaiannya.

Adalah kewajiban seorang dokter untuk mengikuti perkembangan ilmu pengetahuan termasuk apa yang diutarakan oleh Keeton di atas. Dan kalau karena tertinggal ilmunya sampai mengakibatkan pasien menderita cedera, maka tindakan itu juga bisa termasuk kelalaian. Dilihat dari segi etik pun demikian. KODEKI Pasal 18 mencantumkan: "Setiap dokter hendaklah senantiasa mengikuti perkembangan ilmu pengetahuan dan tetap setia kepada cita-cita yang luhur".

\section{d. Tolok Ukur/Standar Kelalaian Me- dis}

Seorang dokter dapat dikatakan mempunyai kesalahan apabila ia pada saat melakukan perbuatan itu dilihat dari segi masyarakat dapat dicela karenanya. Artinya ialah, mengapa ia melakukan perbuatan yang merugikan masyarakat itu, padahal ia mampu untuk mengetahui perbuatan tersebut, dan oleh karena itu seharusnya dapat menghindari untuk berbuat demikian. Apabila seorang dokter melakukannya, ini berarti dirinya memang sengaja melakukan perbuatan tersebut. Karena itu celaannya menjadi: mengapa dokter melakukan perbuatan yang ia mengerti akan berakibat merugikan masyarakat. Dokter tersebut mengetahui kalau perbuatannya itu dilarang.

Kealpaan/kelalaian terjadi apabila seseorang melakukan perbuatan itu karena ia alpa/lalai terhadap kewajiban yang menurut 
tatanan kehidupan masyarakat yang berlaku seharusnya/sepatutnya tidak dilakukan olehnya. Karena itu mengapa ia tidak melakukan kewajiban-kewajiban yang seharusnya/sepatutnya dilakukan, sehingga masyarakat tidak dirugikan. Sedangkan yang dimaksud dengan kesengajaan ialah perbuatan yang diinsafi, dimengerti, dan diketahui sebagai demikian, seorang dokter yang melakukan aborsi (abortus provocatus criminalis) hal ini dilakukan dengan kesengajaan (dolus). Berkaitan dengan hal ini PBB juga tidak pernah bisa secara tegas-tegas melarang anggotanya yang melakukan praktik aborsi, karena belum adanya kesepakatan hukum yang melarang atau membolehkannya. ${ }^{6}$ Adapun profesi medis di Indonesia sendiri dengan tegas menolak aborsi, sehingga tidak ada unsur salah sangka/salah paham. Dengan demikian untuk adanya unsur kesalahan harus ada hubungan yang erat antara keadaan batin pelaku dengan perbuatan yang dilakukan. Keadaan batin pelaku itulah yang menyertai perbuatannya sehingga menimbulkan perbuatan tercela yang berupa kesengajaan dan atau kealpaan/kelalaian. Oleh karena itu dalam kepustakaan disebutkan bahwa kesengajaan - dolus - dan kealpaan atau kelalaian - culpa - merupakan bentuk-bentuk kesalahan.

Dalam terminologi bahasa, kealpaan mengandung arti kekeliruan, yaitu bahwa sikap batin orang yang menimbulkan keadaan yang dilarang itu bukannya menentang larangan tersebut, dia bukannya menghendaki atau menyetujui timbulnya hal yang terlarang itu, tetapi karena kesalahannya, kekeliruannya dalam batin sewaktu berbuat, sehingga menimbulkan keadaan yang dilarang itu, karena ia kurang mengindahkan larangan itu. Dari perbuatannya itu ia telah alpa, lalai atau teledor. Ilmu pengetahuan hukum menyebutkan bahwa kealpaan mengandung dua syarat: tidak mengadakan penduga-duga sebagaimana yang diharuskan oleh hukum, dan tidak mengadakan penghati-hati sebagaimana yang diharuskan oleh hukum.

Yang dimaksud dengan tidak mengadakan penduga-duga dapat terjadi karena 2 (dua) kemungkinan: (a) pelaku delik berpikir bahwa akibat tidak akan terjadi karena perbuatannya itu. Padahal ternyata bahwa pendapatnya itu kemudian ternyata tidak benar. Dalam hal demikian telah terjadi kealpaan yang disadari - bewuste culpa. Pelaku delik tidak mengadakan penduga-duga lebih dulu itu terletak dalam kesalahan pikir atau pandang yang seharusnya dapat ia tepiskan. Kemungkinan ini diinsaf, namun tetap dilakukan juga karena ia percaya akan kebenaran pandangan atau pikirannya; (b) pelaku delik sama sekali tidak mempunyai pikiran bahwa akibat yang dilarang itu mungkin dapat terjadi karena perbuatannya. Dalam hal ini telah terjadi kealpaan yang tidak disadari -onbewuste culpa-. Dalam hal ini tidak mengadakan penduga-duga karena tidak adanya pikiran sama sekali bahwa akan terjadi akibat yang fatal karena perbuatannya itu.

Adapun yang dimaksud dengan tidak mengadakan penghati-hati ialah bahwa pelaku delik tidak mengadakan penelitian serta usaha-usaha pencegahan yang mungkin dapat menjadi kenyataan apabila dalam kondisi tertentu, atau dalam caranya melakukan perbuatan itu akibat tersebut dapat terjadi. Dari uraian tersebut di atas dapat disimpulkan, bahwa kealpaan atau kelalaian hakikatnya mengandung tiga unsur, yaitu: Pertama, pelaku berbuat (atau tidak berbuat), lain daripada apa yang seharusnya ia perbuat (atau tidak berbuat), sehingga dengan berbuat demikian (atau tidak berbuat) telah melakukan perbuatan melawan hukum. Kedua, pelaku telah berbuat lalai, lengah, atau kurang berpikir panjang. Ketiga, per- 
buatan pelaku tersebut dapat dicela, dan oleh karena itu pelaku harus mempertanggungjawabkan akibat yang terjadi karena perbuatannya itu.

Tinjauan dari segi hukum perdata dalam kaitannya dengan kesalahan atau kelalaian dalam melaksanakan profesi dokter berawal dari hubungan antara dua pihak yaitu dokter dan pasien, yang dalam hubungan hukum perdata dapat berkedudukan sebagai penggugat dan tergugat. Antara penggugat dan tergugat (dokter dan pasien) telah terjadi hubungan hukum yang disebut transaksi terapeutik. Transaksi terapeutik tersebut telah terjadi kesepakatan di antara kedua belah pihak untuk masing-masing akan memenuhi syarat-syarat sebagaimana telah diperjanjikan. Dalam hal ini masing-masing pihak baik dokter maupun pasien mempunyai hak dan kewajiban secara timbal balik, yaitu dokter akan mengupayakan kesembuhan, dan pasien akan memberikan imbalan atas upaya yang telah dilakukan oleh dokter tersebut. Gugatan oleh pasien dapat terjadi dalam hal dokter tidak memenuhi apa yang telah dijanjikan. Tidak dipenuhinya janji tersebut disebabkan karena tidak menguasai keluhan pasien yang dapat disebabkan karena sama sekali tidak dipenuhi, atau janji tersebut dipenuhi tetapi tidak sesuai dengan yang telah dijanjikan, atau dipenuhi tetapi lain dengan apa yang telah dijanjikan, sehingga pasien merasa dirugikan.

\section{e. Malpraktik}

Istilah malpraktik atau malpractice menurut Daris, Peter Salim dalam "The Contemporary English Indonesia Dictionary" berarti perbuatan atau tindakan yang salah, yang menunjukkan pada setiap sikap tindakan yang keliru. Sedangkan menurut John M. Echols dan Hassan Sadily dalam Kamus Inggris Indonesia, "malpractice" berarti cara pengobatan pasien yang salah. Adapun ruang lingkupnya mencakup kurangnya kemampuan untuk melaksanakan kewajiban-kewajiban profesional atau didasarkan kepada kepercayaan. Jadi malpraktik merupakan salah satu penyebab perselisihan/konflik antara dokter dengan pasien.

\section{f. Pembuktian Malpraktik}

Ada beberapa sistem atau teori untuk membuktikan perbuatan yang didakwakan. Sistem atau teori pembuktian ini bervariasi menurut waktu dan tempat (negara), yaitu positif wettelijk bewijstheorie, conviction intime, laconvviction raisonnee dan negatef wettelijk. ${ }^{7}$ Kalau kesalahan dokter merupakan kesalahan profesi, maka tidaklah mudah bagi siapa saja yang tidak memahami profesi ini untuk membuktikannya di pengadilan. Meskipun demikian tidak berarti kesalahan dokter tidak mungkin dapat dibuktikan, jadi kalau begitu bagaimana cara pembuktian malpraktik?

Pada criminal malpractice pembuktiannya didasarkan atas dipenuhi tidaknya unsur pidana, sehingga karenanya tergantung dari jenis criminal malpractice yang dituduhkan. Dalam hal dokter dituduh melakukan kealpaan sehingga pasien yang ditangani meninggal dunia, menderita luka berat atau luka sedang, maka yang harus dibuktikan adalah adanya unsur perbuatan yang salah yang dilakukan dengan sikap batin berupa alpa atau kurang hati-hati. Perlu dipahami bahwa tidak setiap hasil pengobatan yang tidak sesuai dengan harapan pasien merupakan bukti adanya criminal malpractice mengingat kejadian semacam itu juga dapat merupakan bagian dari risiko tindakan medis. Kesalahan diagnosis juga tidak boleh secara otomatis dijadikan ukuran adanya criminal practice sebab banyak faktor yang mempengaruhi ketepatan diagnosis, yang kadang-kadang sebagian faktor tersebut berada di luar kekuasaan dokter. Kedua hal di 
atas hanya dapat dijadikan persangkaan yang masih harus dibuktikan unsur-unsur pidananya.

Jika terbukti bersalah maka dokter dapat dipidana sesuai jenis tindak pidana yang dilakukannya. Selain itu dokter masih dapat digugat melalui peradilan perdata atas dasar perbuatan melawan hukum (onrechtmatige daad). Pada malpraktik perdata pembuktiannya dapat dilakukan melalui dua cara, yaitu langsung atau tak langsung. Secara langsung, yaitu dengan membuktikan keempat unsurnya secara langsung, yang terdiri atas unsur kewajiban, menelantarkan kewajiban, rusaknya kesehatan dan adanya hubungan langsung antara tindakan menelantarkan kewajiban dengan rusaknya kesehatan. Adapun secara tak langsung, yaitu dengan mencari fakta-fakta yang berdasarkan doktrin res ipsa loquitor dapat membuktikan adanya kesalahan di pihak dokter. Namun tidak semua kelalaian dokter meninggalkan fakta semacam itu. Doktrin res ipsa loquitor ini sebetulnya merupakan varian dari 'doctrine of common knowledge', hanya saja di sini masih diperlukan sedikit bantuan kesaksian dari ahli untuk menguji apakah fakta yang ditemukan memang dapat dijadikan bukti adanya kelalaian dokter.

Apabila ada gunting atau tang tertinggal dalam perut pasien yang menjalani operasi, maka gunting atau tang itu berdasarkan doktrin res ipsa loquitor, dapat dijadikan fakta yang secara tidak langsung dapat membuktikan kesalahan dokter, sebab gunting atau tang itu tak mungkin tertinggal kalau tak ada kelalaian, Gunting atau tang yang tertinggal itu berada di bawah tanggung jawab dokter, Pasien dalam keadaan terbius, sehingga tidak mungkin dapat memberi andil terhadap tertinggalnya alat-alat tersebut. Dari uraian tersebut di atas dapat disimpulkan bahwa penyebab dari perselisihan konflik antara dokter dan pasien adalah adanya kesalahan atau kelalaian yang menimbulkan malpraktik dan berakibat kerugian yang diderita oleh pasien.

2. Pertanggungjawaban Dokter terhadap Pasien dalam Hal Malpraktik

\section{a. Pertanggungjawaban}

Yang dimaksud pertanggungjawaban hukum dokter di sini adalah pertanggungjawaban, yaitu suatu "keterikatan" dokter terhadap ketentuan-ketentuan hukum dalam menjalankan profesinya. Tanggung jawab seorang dokter dalam bidang hukum, bisa terjadi dalam bidang hukum perdata dan pidana. Dokter dinilai bertanggung jawab dalam bidang hukum perdata jika dokter tidak melaksanakan kewajibannya (ingkar janji/wanprestasi), yaitu tidak memberikan prestasinya sebagaimana yang telah disepakati juga bisa terjadi karena perbuatan yang melawan hukum.

Tindakan dokter yang dapat dikategorikan wanprestasi antara lain; tidak melakukan apa yang menurut kesepakatannya wajib dilakukan, melakukan apa yang menurut kesepakatannya wajib dilakukan tetapi terlambat, melakukan apa yang menurut kesepakatannya wajib dilakukan tetapi tidak sempurna dan melakukan apa yang menurut kesepakatan tidak seharusnya dilakukan. Dalam hal demikian dokter dapat dipersalahkan melakukan perbuatan yang melawan hukum (onrechtsmatige daad). Jadi tindakan dokter dinilai melanggar Pasal 1365 KUH Perdata yaitu: "Tiap perbuatan melanggar hukum, yang membawa kerugian kepada seorang lain, mewajibkan orang yang karena salahnya menerbitkan kerugian itu, mengganti kerugian tersebut".

Jadi seorang dokter harus bertanggungjawab atas kesalahan/kelalaiannya yang mengakibatkan pasien cedera atau bahkan meninggal dunia. Tanggung jawab itu berupa pengganti kerugian baik materiil maupun immaterial terhadap pasien/keluarganya. Contoh perbuatan melanggar hukum adalah apabila seorang dokter bedah karena kelalaiannya telah meninggalkan kain kasa/ 
alat dalam tubuh pasien, sehingga pasien mengalami infeksi sehingga mengakibatkan pasien tersebut menderita dan dapat pula karena komplikasinya menyebabkan pasien tersebut meninggal dunia.

Dokter tidak saja bertanggung jawab atas kelalaian yang dilakukannya tetapi juga atas kelalaian yang dilakukan oleh orangorang yang menjadi tanggungannya. Contoh, seorang dokter ahli bedah bertanggung jawab atas perbuatan yang dilakukan oleh perawat yang membantu dalam pelaksanaan operasi di kamar bedah. Tanggung jawab dapat bersifat individual atau korporasi. Selain itu dapat pula dialihkan kepada pihak lain berdasarkan principle of vicarious liability. Dengan prinsip ini maka rumah sakit dapat bertanggung gugat atas kesalahan yang dilakukan dokterdokternya, asalkan dapat dibuktikan bahwa tindakan dokter itu dalam rangka melaksanakan kewajiban rumah sakit.

\section{b. Karena Wanprestasi}

Pengertian wanprestasi ialah suatu keadaan dimana seseorang tidak memenuhi kewajibannya yang didasarkan pada suatu perjanjian atau kontrak. Dalam hal malpraktik oleh dokter gugatan atas dasar wanprestasi itu harus dibuktikan bahwa dokter itu benar-benar telah mengadakan perjanjian, kemudian dia telah melakukan wanprestasi terhadap perjanjian tersebut (yang harus didasarkan pada kesalahan profesi). Pasien harus mempunyai bukti-bukti kerugian akibat tidak dipenuhinya kewajiban dokter sesuai dengan standar profesi medis yang berlaku dalam suatu kontrak terapeutik. Tetapi dalam praktiknya tidak mudah untuk melaksanakannya, karena pasien juga tidak mempunyai cukup informasi dari dokter mengenai tindakan-tindakan apa saja yang merupakan kewajiban dokter dalam suatu kontrak terapeutik. Hal ini yang sangat sulit dalam pembuktiannya karena mengingat perikatan antara dokter dan pasien adalah bersifat inspaningsverbintenis.

\section{c. Karena Perbuatan Melawan Hu- kum (Onrechtmatige Daad)}

Berdasarkan Pasal 1365 KUH Perdata pasien bisa menggugat seorang dokter oleh karena telah melakukan perbuatan yang melanggar hukum, seperti yang diatur di dalam Pasal 1365 Kitab Undang-Undang Hukum Perdata yang menyebutkan bahwa: "Tiap perbuatan melanggar hukum, yang membawa kerugian kepada orang lain, mewajibkan orang yang karena salahnya menerbitkan kesalahan itu, mengganti kerugian tersebut".

Undang-Undang sama sekali tidak memberikan batasan tentang perbuatan melawan hukum, yang harus ditafsirkan oleh peradilan. Semula dimaksudkan segala sesuatu yang bertentangan dengan Undang-Undang, jadi suatu perbuatan melawan undang-undang. Akan tetapi sejak tahun 1919 yurisprudensi tetap, telah memberikan pengertian yaitu setiap tindakan atau kelalaian baik yang: - melanggar hak orang lain - bertentangan dengan kewajiban hukum diri sendiri - menyalahi pandangan etis yang umumnya dianut (adat istiadat yang baik) - tidak sesuai dengan kepatuhan dan kecermatan sebagai persyaratan tentang diri dan benda orang seorang dalam pergaulan hidup.

Juga sedikitnya harus ada kesalahan yang mendasari perbuatan tersebut dan antara tindakan tak wajar atau kelalaian dan kerugian yang terjadi harus terdapat hubungan sebab akibat yang jelas. Pengertian perbuatan melawan hukum dalam arti luas berdasarkan Arrest Hoge Raad 31 Januari 1919 mengenai Arrest Lindeboum melawan Cohen adalah mencakup pengertian berbuat atau tidak berbuat yang melanggar hak orang lain, dan bertentangan dengan kewajiban hukum sendiri atau kesusilaan atau kepatutan dalam masyarakat, baik terhadap diri atau benda orang lain. Ini berarti, kesalahan diartikan secara luas meliputi kesengajaan, kelalaian dan kurang hati-hati. Dan mengenai kesalahan dokter dalam menjalankan 
profesinya atau kesalahan profesional pada dasarnya berkaitan dengan kewajiban yang timbul karena profesinya atau disebut kewajiban profesional.

Selain dapat dituntut atas dasar wanprestasi dan melawan hukum seperti tersebut di atas, dokter juga dapat dituntut atas dasar kelalaian, sehingga menimbulkan kerugian. Gugatan atas dasar kelalaian ini diatur dalam Pasal 1366 Kitab Undang-Undang Hukum Perdata, yang bunyinya sebagai berikut, "Setiap orang bertanggung jawab tidak saja untuk kerugian yang disebabkan karena perbuatannya, tetapi juga untuk kerugian yang disebabkan karena kelalaian atau kurang hati-hatinya".

\section{d. Tanggung Jawab Pidana}

Kesalahan atau kelalaian tenaga kesehatan dapat terjadi di bidang hukum pidana, diatur antara lain dalam Pasal 263, 267, 294 ayat (2), 299, 304, 322, 344, 347, 348, 349, 351, 359, 360, 361, 531 Kitab Undang-Undang Hukum Pidana. Mengenai criminal malpractice yang berupa kecerobohan/kelalaian banyak kasus yang muncul di Rumah Sakit. Dalam literatur hukum kedokteran negara Anglo-Saxon antara lain dari Taylor dikatakan bahwa seorang dokter baru dapat dipersalahkan dan digugat menurut hukum apabila dia sudah memenuhi syarat 4-D, yaitu: duty (kewajiban), derelictions of that duty (penyimpangan kewajiban), damage (kerugian), direct causal relationship (berkaitan langsung).

Duty atau kewajiban bisa berdasarkan perjanjian (ius contractu) atau menurut undang-undang (ius delicto). Juga adalah kewajiban dokter untuk bekerja berdasarkan standar profesi. Kini adalah kewajiban dokter pula untuk memperoleh informed consent, dalam arti wajib memberikan informasi yang cukup dan mengerti sebelum mengambil tindakannya. Informasi itu mencakup antara lain: risiko yang melekat pada tindakan, kemungkinan timbul efek sampingan, alternatif lain jika ada, apa akibat jika tidak dilakukan dan sebagainya. Peraturan tentang persetujuan tindakan medis sudah diatur dalam Peraturan Menteri Kesehatan RI No. 585 Tahun 1989.

Penentuan bahwa adanya penyimpangan dari standar profesi medis adalah sesuatu yang didasarkan atas fakta-fakta secara kasuistis yang harus dipertimbangkan oleh para ahli dan saksi ahli. Namun sering kali pasien mencampuradukkan antara akibat dan kelalaian. Bahwa timbul akibat negatif atau keadaan pasien yang tidak bertambah baik belum membuktikan adanya kelalaian. Kelalaian itu harus dibuktikan dengan jelas. Harus dibuktikan dahulu bahwa dokter itu telah melakukan 'breach of duty'.

Damage berarti kerugian yang diderita pasien itu harus berwujud dalam bentuk fisik, finansial, emosional atau berbagai kategori kerugian lainnya, di dalam kepustakaan dibedakan menjadi kerugian umum (general damages) termasuk kehilangan pendapatan yang akan diterima, kesakitan dan penderitaan dan kerugian khusus (special damages) kerugian finansial nyata yang harus dikeluarkan, seperti biaya pengobatan, gaji yang tidak diterima.

Dari segi pidana sebagaimana diatur dalam Kitab Undang-Undang Pidana Indonesia dan dari sekian banyak pasal-pasal pidana yang menjerat perbuatan malpraktek yang dilakukan oleh dokter terhadap pasiennya dapat dipidana, sebab jika suatu perbuatan secara formal dan material dapat dikualifikasikan sebagai perbuatan tercela, maka perbuatan tersebut dapat dipidana (merupakan suatu delik), ${ }^{8}$ karena menurut kode etik kedokteran malpraktek merupakan perbuatan tercela. Sedangkan menurut norma hukum

Widiada Gunakarya, "Sifat Melawan Hukum Material vs HAM Dalam Pemberantasan Tindak Pidana Korupsi”, Jurnal Wawasan Hukum, Vol. 16, No. 10, Februari 2007, hlm. 31. 
pidana sebagaimana diatur dalam KUHP malpraktek dapat dipidana berdasarkan Pasal 359 dan 360 KUHP. Pasal 359 tersebut menyatakan bahwa: "Barangsiapa karena salahnya menyebabkan matinya orang dihukum penjara selama-lamanya lima tahun atau kurungan selama-lamanya satu tahun".

Dari bunyi pasal ini kita bisa mengambil satu pengertian bahwa matinya orang ini sama sekali tidak dimaksud dan bukan merupakan tujuan dari pelaku tindak pidana, akan tetapi kematian tersebut hanya merupakan akibat dari kurang hati-hatinya atau lalainya pelaku (culpa delict). Hal ini bisa terjadi ketika seorang dokter melakukan pembedahan terhadap seorang pasien, tapi ternyata selesai pasien dibedah ada benda yang tertinggal di dalam tubuh pasien (bisa perban atau alat pemotong). Ini menimbulkan kematian pasien. Akan tetapi tertinggalnya perban atau alat pemotong dalam tubuh pasien itu dilakukan tidak dengan sengaja, akan tetapi karena kelalaiannya atau karena kekurang hati-hatiannya dari dokter tersebut. Sebab apabila tertinggalnya perban atau alat potong itu dilakukan dengan sengaja, maka dokter itu bisa dijerat dengan pasal 338 KUHP (pembunuhan biasa) atau pasal 340 KUHP (pembunuhan yang direncanakan). Pasal 360 ayat (1) mengatur bahwa: "Barangsiapa karena kesalahannya menyebabkan orang luka berat dihukum dengan hukuman penjara selamalamanya lima tahun atau hukuman kurungan selama-lamanya satu tahun". Dalam Pasal 360 ayat (2) diatur pula bahwa: "Barangsiapa karena kesalahannya menyebabkan orang luka sedemikian rupa sehingga orang itu menjadi sakit sementara atau tidak dapat menjalankan jabatannya atau pekerjaannya sementara, dihukum dengan hukuman penjara selama-lamanya sembilan bulan atau hukuman kurungan selama-lamanya enam bulan atau hukuman denda setinggi-tingginya
Rp.4.500,-".

Rumusan pasal 360 ayat (1) dan (2) ini, hampir sama dengan rumusan pasal 359. Bedanya terletak pada akibat dari perbuatan pelaku. Kalau pada pasal 359 akibatnya adalah meninggal dunia, tapi dalam pasal 360 ayat (1) akibatnya adalah orang (pasien) luka berat, sedangkan dalam ayat (2) akibatnya adalah luka sedemikian rupa sehingga orang itu menjadi sakit sementara atau tidak dapat menjalankan jabatannya atau pekerjaannya sementara. Delik Pasal 359 KUHP dan Pasal 360 ayat (1) dan ayat (2) KUHP yang berwenang melakukan penyidikannya adalah pejabat Polisi Negara Republik Indonesia, sebagaimana diatur dalam KUHAP: "Penyidik adalah pejabat polisi negara Republik Indonesia". ${ }^{9}$ Dari uraian tersebut di atas maka dapat ditarik kesimpulan bahwa pertanggungjawaban dokter terhadap pasien dalam hal terjadi malpraktek oleh dokter bisa berupa tanggung jawab hukum perdata dan pidana.

\section{Kesimpulan}

Dari pembahasan seperti diuraikan di atas maka dapat disimpulkan, bahwa penyebab dari perselisihan konflik antara dokter dan pasien adalah adanya kesalahan/kelalaian/kealpaan yang menimbulkan malpraktek dan berakibat kerugian yang diderita oleh pasien. Kesalahan dan kelalaian/ kealpaan terjadi apabila seseorang melakukan perbuatan itu karena ia lalai/alpa terhadap kewajiban yang menurut tatanan kehidupan masyarakat yang berlaku atau secara teknis harus dilakukan atau seharusnya/sepatutnya tidak dilakukan olehnya. Karena itu mengapa ia tidak melakukan kewajibankewajiban yang seharusnya/sepatutnya dilakukan, sehingga masyarakat tidak dirugikan. Contoh tindakan teknis yang harus dilakukan, misalnya seorang dokter pada waktu melakukan operasi di rongga perut pasien, selesai operasi pada saat penutup kembali rongga perut pasien ternyata di rongga perut 
pasien tertinggal gunting yang digunakan bekas alat operasi dimaksud, karena kekhilafannya atau kealpaanya. Akibat tertinggalnya gunting di rongga perut pasien tadi, pasien setelah selesai operasi menderita sakit dan selanjutnya meninggal dunia.

Bahwa pertanggungjawaban dokter terhadap pasien dalam hal terjadi malpraktek yang diakibatkan oleh kesalahan/kelalaian/kealpaan dokter bisa berupa tanggung jawab hukum perdata dan pidana. Tindakan dokter yang dapat dikategorikan karena kesalahan/kelalaian/kealpaan antara lain: yaitu kesalahan/kelalaian/kealpaan yang tidak melakukan apa yang menurut kesepakatannya wajib dilakukan, melakukan apa yang menurut kesepakatannya wajib dilakukan tetapi terlambat, melakukan apa yang menurut kesepakatannya wajib dilakukan tetapi tidak sempurna dan melakukan apa yang menurut kesepakatan tidak seharusnya dilakukan. Kesalahan/kelalaian/kealpaan dokter dapat terjadi di bidang hukum perdata dan pidana. Dalam hukum perdata kesalahan/kelalaian/kealpaan yang menimbulkan malpraktik dilakukan oleh dokter bisa digugat perdata berdasarkan Pasal 1365 KUH Perdata yaitu karena melakukan perbuatan melawan hukum atau onrechtsmatige daad.

Sedangkan kesalahan/kelalaian/kealpaan yang menimbulkan malpraktek dilakukan oleh dokter apabila menimbulkan luka dapat dituntut dengan Pasal 360 ayat (1) KUHP, yaitu "Barangsiapa karena kealpaannya menyebabkan matinya orang lain mendapat luka-luka, diancam dengan pidana penjara paling lama lima tahun atau kurungan paling lama satu tahun". Apabila malpraktik itu menimbulkan kematian, maka dapat dituntut berdasarkan Pasal 359 KUHP, yaitu: "Barangsiapa karena kealpaannya menyebabkan matinya orang lain, diancam dengan pidana penjara paling lama lima tahun atau kurungan paling lama satu tahun".

\section{DAFTAR PUSTAKA}

\section{A. Buku}

Blumer, Herbert, 1969, Symbolic Interactionism: Perspective and Method, Englewood Cliff, Prentice Hall, N.J.

Guwandi, J., 1993, Etika dan Hukum Kedokteran. Fakultas Kedokteran, Universitas Indonesia, Jakarta.

Hamzah, Andi, 1996, Hukum Acara Pidana Indonesia, Sinar Grafika, Jakarta.

Panitia Etika Rumah Sakit, 1991, Etika Rumah Sakit di Rumah Sakit Dr. Cipto Mangunkusumo, RS Rumah Sakit Dr. Cipto Mangunkusumo, Jakarta.

\section{B. Artikel Jurnal}

Gunakarya, Widiada, "Sifat Melawan Hukum Material vs HAM Dalam Pemberantasan Tindak Pidana Korupsi”, Jurnal Wawasan Hukum, Vol. 16, No. 10, Februari 2007.

M. Hamdan, "Jenis-Jenis Putusan Hakim dalam Perkara Pidana (Suatu Catatan tentang Pembaruan KUHAP)", Jurnal Hukum Pemban- gunan, Tahun Ke-40, No. 4, Oktober 2010.

Pakpahan, Rudy Hendra dan Eka N.A.M. Sihombing, "Tanggung Jawab Negara dalam Pelaksanaan Jaminan Sosial", Jurnal Legislasi Indonesia, Vol. 9, No. 2, Juli 2012.

Rukmini, Mien, "Pengaturan Pelaksanaan Aborsi Akibat Perkosaan", Jurnal Ilmu Hukum Litigasi, Vol. 4, No. 3, Oktober 2003.

Yulia, Rena, "Perlindungan Hukum terhadap Korban Kejahatan", Jurnal Wawasan Hukum, Vol. 18, No. 1, Februari 2008.

\section{Makalah}

Sutrisno, S., "Tanggung Jawab Dokter di Bidang Hukum Perdata. Segi-Segi Hukum Pembuktian", Makalah, Seminar Malpraktek Kedokteran, Semarang, 29 Juni 1991.

\section{Peraturan Perundang-Undangan}

Kitab Undang-Undang Hukum Acara Pidana.

Peraturan Pemerintah No. 32 Tahun 1996 tentang Tenaga Kesehatan. 